Síntese - Rev. de Filosofia

v. 29 N. 94 (2002): 191-220

\title{
O ROSTO COMO APELO À RESPONSABILIDADE E À JUSTIÇA EM LEVINAS*
}

Paulo César Nodari

PUCRS

Resumo: 0 objetivo deste artigo é mostrar que, em Levinas, o rosto é a manifestação do outro infinitamente transcendente. De acordo com as duas obras principais de Levinas: Totalité et infini e Autrement qu'être ou delà de l'essence, buscaremos explicitar a interpretação levinasiana do rosto. Tentaremos, então, primeiramente, analisar como, de acordo com a crítica à ontologia ocidental, Levinas instaura a ética como "filosofia primeira", e, posteriormente, mostrar como, em Levinas, o rosto do outro se torna apelo à responsabilidade e à justiça.

Palavras-chave: Levinas, Ética, Outro, Rosto, Responsabilidade, Justiça.

Abstract: The aim of this article is to show that in Levinas the face is the manifestation of the other infinitely transcendent. In accordance with the two main Levinas's works: Totalité et infini and Autrement qu'être ou delà de l'essence, we will seek the explanation of levinasian's interpretation of face. Then, we will try to analyze, according to the critique of occidental ontology, how Levinas establishes the ethics such as "first philosophy" and show how in Levinas the face of the other becomes appeal to the responsibility and the justice.

Key words: Levinas, Ethics, Other, Face, Responsibility, Justice.

\footnotetext{
* Este artigo é fruto de um trabalho monográfico elaborado e apresentado como requisito para avaliação na disciplina Subjetividade, consciência intencional e sensibilidade em Levinas, no Curso de Pós-graduação em Filosofia, na Pontifícia Universidade Católica do Rio Grande do Sul (PUCRS), ministrada pelo Prof. Dr. Pergentino Stefano Pivatto, no Primeiro Semestre de 2001.
} 


\section{Introdução: da ontologia à ética como "filosofia primeira"}

ão há dúvidas de que a obra e o pensamento de Levinas são melhor compreendidos quando situados no contexto e no

horizonte dos acontecimentos do século $X^{1}{ }^{1}$, dentre os quais gostaríamos de lembrar sobremaneira as duas guerras mundiais ${ }^{2}$, a crise da razão e das ciências humanas ${ }^{3}$, o problema ecológico, a disse-

${ }^{1}$ Cf. P. S. Pivatto, Ética da alteridade, in M. A. De Oliveira (org.), Correntes fundamentais da Ética contemporânea, Petrópolis, Vozes, 2000, 79.

2 Segundo Levinas, o estado de guerra suspende a moral; impede a manifestar a exterioridade e o outro como outro, destrói a identidade do mesmo. Ver E. LEVInAS, Totalidade e infinito, Lisboa, Edições 70, 1988, 9-10.

3 "A história do espírito humano, nesse seu estágio recente que convencionamos denominar modernidade, oferece-nos um de seus mais surpreendentes e inquietantes paradoxos. Trata-se do pertinaz esforço, suportado por variadas teorias reducionistas, para 'desconstruir' o conhecimento na sua especificidade humana, na fulgurante originalidade que o distingue de qualquer outra atividade em nós e em torno de nós. Conhecer para desconhecer: eis o alvo gritantemente paradoxal que parece perseguido pelas ciências dos nossos dias, que acumulam uma soma enciclopédica de saberes sobre os aspectos neurofisiológicos, lógicos, psicológicos, sociológicos, lingüísticos do conhecimento. Saberes úteis e mesmo necessários, mas que, na sua intenção normalmente reducionista, acabam por obscurecer o foco luminoso da própria essência do conhecimento, do qual irradia sua irredutível originalidade humana e no qual se revela a mais profunda e como que abissal experiência que nos é dado fazer da nossa identidade: a de conhecermos em nós mesmos a realidade que se abre diante de nós." [H. C. DE LIMA VAZ, Tópicos para uma metafísica do conhecimento, in R. A. ULLmann (org.), Consecratio Mundi: Festschrift em homenagem a Urbano Zilles, Porto Alegre, EDIPUCRS, 1998, 436]. Segundo Manfredo de Oliveira, a "humanidade contemporânea faz aparecer, às claras, o paradoxo implícito na civilização moderna: esta levanta a pretensão de ser uma civilização unicamente radicada na razão. Porém, uma vez que reduziu a razão à manipulação de fenômenos, por um lado, aumentou enormemente a capacidade humana de dispor sobre os fenômenos, de tal modo que, hoje, as conseqüências das ações humanas se estendem ao planeta; por outro lado, a própria redução da razão à esfera da manipulação eficaz de fenômenos a torna incapaz de se confrontar eticamente com os próprios problemas daí decorrentes a respeito da vida humana e seu destino. No que toca ao cerne mesmo de sua vida, o ser humano está, hoje, preso a decisões que ele não pode mais legitimar, portanto, submetido às forças cegas da história, privado de pontos de referência autênticos, uma vez que, até por falsa modéstia, ele deixa de pôr as perguntas radicais sobre o sentido e o fundamento último da vida humana, pessoal e social." [M. A. DE OLIVEIRA, Considerações sobre a filosofia na encíclica Fides et Ratio, Revista Razão e Fé 1 (1999) 18)]. Na perspectiva da crise da razão e das ciências humanas, há uma vasta e excelente bibliografia. Todavia, acerca da crise da razão na sua relação com a fé, gostaríamos de remeter à leitura e análise da encíclica de J õ̃o Paulo II, Fides et Ratio, tendo consciência da problemática de fundo que perpassa sua sistematização. A razão, apesar dos imensos progressos da humanidade, tem uma concepção reducionista de si mesma, pois limitou-se a uma perspectiva antropocêntrica. "Foram construídos sistemas de pensamento complexos, que deram os seus frutos nos diversos âmbitos do conhecimento, favorecendo o progresso da cultura e da história. 
minação e a perda do sentido da vida ${ }^{4}$. Neste contexto, Levinas construirá sua proposta ética, da qual tentaremos, mesmo que propedeuticamente, esboçar alguns aspectos concernentes à temática escol hida para esta reflexão: "O rosto - epifania do totalmente outrem é apelo à responsabilidade e à justiça".

A leitura das obras filosóficas de Levinas permite sustentar que, na arquitetura do seu pensamento, a ética surge progressivamente como tema central, até ser definitivamente estabelecida como "filosofia primeira", anterior a qualquer outra filosofia possível ${ }^{5}$. Prova disso está no fato de que a "ética precede a ontologia" ou a "ética é a filosofia primeira", originalidade do pensamento de Levinas ${ }^{6}$, já se tornaram famosas e aparecem como resumidoras do pensamento filosófico de Levinas em seu significado essencial ${ }^{7}$.

"Ao prevenir contra o perigo de simplificações e de fáceis desvios, cumpre reafirmar que essas fórmulas não podem ser compreendidas formalisticamente. Indicam, é claro, a primazia da Ética sobre a Ontologia. Mas esta primazia resulta de todo um processo em que se põe em cheque o império do seressência comumente entendido na tradição ocidental e se instaura, nas brechas abertas da ruptura do ser, uma relação melhor com a alteridade inabarcável pela intencionalidade e, contudo, incontornável pelo eu. A alteridade, aqui,

A antropologia, a lógica, as ciências da natureza, a história, a lingüística, de algum modo todo o universo do saber foi abarcado. Todavia, os resultados positivos alcançados não devem levar a transcurar o fato de que essa mesma razão, porque ocupada a investigar de maneira unilateral o homem como objeto, parece ter-se esquecido de que este é sempre chamado a voltar-se também para uma realidade que o transcende" (J oão Paulo II, Fides et Ratio, n. 5, São Paulo, Paulus, 21998). Para maior aprofundamento desta relação, ver também, M. A. DE Oliveira, Diálogos entre razão e fé, São Paulo, Paulinas, 2000.

${ }^{4} \mathrm{O}$ homem atual parece não ter mais referenciais, parece viver um profundo vazio moral. Vive-se, por um lado, uma época de conhecimentos eminentíssimos, num mundo cheio de informações e facilidades jamais imaginadas e sonhadas outrora, e, por outro lado, num mundo que, pouco a pouco, converte o homem num homem superficial, indiferente, permissivo, que vive num vazio moral sem precedentes. Acerca desta problemática, ver P. C. NoDARI, Panorâmica ética da época atual, Teocumunicação v. 30, no 129 (2000) 433-450.

${ }_{5}$ Cf. M. L. Costa, Levinas: uma introdução, Petrópolis, Vozes, 2000, 19.

${ }^{6}$ A originalidade de Levinas se manifesta no deslocamento do ético à posição de "filosofia primeira". Não funda a ética, como na tradição cristã-ocidental, como um edifício especultivo-dedutivo-sistemático. Não a funda, como Kant, em um ideal de humanidade comum a mim e aos outros, ou, como Apel e Habermas, na estrutura transcendental de um agir comunicativo, pois, segundo ele, estas propostas mantêm ainda a centralidade do eu como portador de responsabilidade. A proposta é outra. Não a de uma ética da responsabilidade, mas como responsabilidade, cuja dedicação ao outro é a própria estrutura que nos constitui enquanto sujeitos. Ver L. Bordin, J udaísmo e Filosofia em Emmanuel Levinas. À escuta de uma perene e antiga sabedoria, Síntese v. 25, no 83 (1998) 559. 7 Cf. P. S. Pivatto, A ética de Levinas e o sentido do humano: crítica à Ética ocidental e seus pressupostos, Veritas v. 37, no 147 (1992) 328. 
deve ser entendida como rosto, é o outro presente e seu vestígio que remanda para um passado para sempre irrecuperável. Haveria, pois, uma razão mais profunda que a razão conhecida, mas não seguida pela prática filosófica ocidental, que preferiu quase sempre a razão da autonomia do eu às vicissitudes de uma relação transcendente. Percebe-se que a Ética, assim como Levinas a propõe, ergue-se sobre os pilares da razão mais profunda e se estende em relações assimétricas. Conseqüentemente, a Ética não será entendida como uma ciência regional ou como uma região da Ontologia-M etafísica, nem será uma ética da alteridade ou ética heterônoma, ou ética como responsabilidade, sem perfazer qualquer forma de totalidade. Na evolução do pensamento do autor, a Ética chegará a ser pensada até como uma espécie de estrutura arcaica e anárquica da própria subjetividade, rompendo com teses tradicionais relativas à identidade" ${ }^{8}$.

De acordo com Levinas, a filosofia moderna ocidental caracteriza-se fundamentalmente pela noção de sujeito e por suas conseqüentes implicações, tais como a centralidade do problema do conhecimento, a problemática da relação sujeito-objeto e a problemática constituição do sujeito e do mundo․ A tradição filosófica, segundo Levinas, sempre privilegiou a relação que liga o conhecimento ao ser como objeto do conhecimento ou como objeto cognoscível. Nesta ordem, a ontologia aprisiona o ser no campo do conhecimento, e o ser perde sua identidade e sua consistência no entendimento do sujeito cognoscente ${ }^{10}$. Em última análise, o problema subjacente a toda problemática é a questão do ser, a saída do ser e o esforço para não deixar-se apanhar pelo nãoser. "A obra de ser do ser é permanecer no ser e não deixar de ser" ${ }^{11}$. Na perspectiva de Levinas, a ontologia só pode relacionar-se com o ser neutralizando- $0^{12}$. Na medida em que neutraliza 0 ser, ela pode compreendê-lo e abarcá-lo.

\footnotetext{
8 I bidem, 328.

${ }^{9}$ Cf. M. L. Costa, op. cit., 52.

10 "Pour Levinas, la tradition philosophique toujours privilégié la relation qui lie la connaissance à l'être comme objet de connaissance (ou comme objet connaissable). Par cette activité, le sujet connaissant cherche à établir une équivalence entre la pensée et le pensé, l'idée et l'objet qu'elle vise, le connaissant et le connu. Dans cet ordre d'idées, I'ontologie emprisonne l'être dans le champ de la connaissance. L'être perd son identité et sa consistance dans l'entendement du sujet connaissant." (V. Tsongo Luutu, Penser le socio-politique avec Emmanuel Levinas, Lyon, Profac, 1993, 12).

${ }_{11}$ M. L. Costa, op. cit., 23.

12 A questão essencial é, portanto, o sentido do ser que marcou todo este processo histórico e que está na base das formas de organização, das estruturas culturais, das codificações de ética e leis civis e penais, enfim, na base de tudo o que constitui nossa história está a concepção da ordem do ser como expansão o que faz com que, apesar das boas intenções, a ética permaneça sempre à mercê do jogo dos vencedores e a civilização ocidental essencialmente egoísta e penetrada de violência. A este respeito, ver P. S. Pivatto, Ética da alteridade, 79-97.
} 
"A ontologia traduz, no fundo, uma filosofia do poder e da violência, ou ainda, a dominação imperialista, a tirania e o poder do Estado. 0 primado do ser sobre o ente (Heidegger), que não escapa a este primado da violência, será um dos alvos decisivos nas críticas de Levinas à ontologia" ${ }^{13}$.

A ontologia, como filosofia primeira, é uma filosofia do poder. 0 caminho de todo o Ocidente foi uma redução de toda a alteridade à mesmidade. A ontologia causou, assim, uma luta entre os poderes assimiladores, cuja regra do jogo consiste em reduzir a identidade do outro à identidade do eu. 0 mesmo provoca necessariamente a abolição de toda exterioridade, assim como não reconhece mais uma vontade superior a si própria ${ }^{14}$. Com as palavras de Levinas, "uma redução do Outro ao $\mathrm{M}$ esmo, pela intervenção de um termo médio e neutro que assegura a inteligência do ser"15. O conhecimento foi interpretado como assimilação. 0 eu autônomo determinou as regras do jogo, tudo sendo esclarecido e modelado pela consciência do eu. 0 outro foi tematizado a partir do horizonte de compreensão do eu. "Não é, portanto, uma relação com o outro como tal, mas a redução do Outro ao Mesmo"16. O eu se constitui no acontecimento ontológico por excelência.

"O primado do M esmo foi a lição de Sócrates: nada receber de Outrem a não ser o que já está em mim, como se, desde toda a eternidade, eu já possuísse o que me vem de fora. Nada receber ou ser livre. A liberdade não se assemel ha à caprichosa espontaneidade do livre arbítrio. 0 seu sentido último tem a ver com a permanência no M esmo, que éa Razão. $O$ conhecimento éo desdobramento dessa identidade, é liberdade. 0 facto de a razão ser no fim de contas a manifestação de uma liberdade, neutralizando o outro e englobando-o, não pode surpreender, a partir do momento em que se disse que a razão soberana apenas se conhece a si própria, que nada mais a limita. A neutralização do Outro, que se torna tema ou objecto - que aparece, isto é, se coloca na claridade - é precisamente a sua redução ao M esmo" ${ }^{17}$.

Nesta perspectiva, segundo Levinas, a "filosofia do poder, a ontologia, como filosofia primeira que não põe em questão o Mesmo, é uma filosofia da injustiça"18, porque acaba resolvendo todos os conflitos entre 0 mesmo e o outro, reduzindo este àquele e constituindo-se num

\footnotetext{
${ }_{13}$ M. FABRI, Desencantando a ontologia: subjetividade e sentido ético em Levinas, Porto Alegre, EDIPUCRS, 1997, 13.

14 "L'ontologie cautionne ainsi la lutte entre les pouvoirs assimilateurs dont la règle de jeu consiste á réduire l'identité de l'autre à la sienne propre. C'est cet aspect impérialiste de la philosophie que Levinas dénonce dans Totalité et Infini" (V. Tsongo LuUtu, op. cit., 16).

${ }^{15} \mathrm{E}$. Levinas, Totalidade e infinito, 31.

16 Ibidem, 33.

17 I bidem, 31.

18 I bidem, 34.
} 
movimento dentro do mesmo antes da obrigação em relação ao outro ${ }^{19}$. É urgente, por conseguinte, inverter os termos. Levinas, na obra Totalidade e Infinito, diz expressamente que seu esforço vai no sentido de captar no discurso uma relação não alérgica com a alteridade. A relação ética dirige-se ao ser na sua exterioridade absoluta e cumpre a própria intenção que anima a caminhada para a verdade ${ }^{20}$. 0 outro, então, como presença e ordenamento permite a Levinas extrair um critério filosófico para criticar a auto-suficiência e o perigo de encantamento da própria ontologia ${ }^{21}$. Em Levinas, por conseguinte, a ética não funciona como um substantivo nomeando um estado de coisas, antes, como modalidade determinando o sentido de uma relação com 0 outro. A ética não é um sistema de normas racionais. A ética levinasiana, então, implica a recusa da estabilidade do ser, nunca é, de fato, um discurso sobre as condições de possibilidade do agir moral segundo regras e normas 22 . É, em contrapartida, pensada como desencantamento e recusa de um mundo em que o outro caiu no esquecimento do $\operatorname{ser}^{23}$.

Impõe-se aqui uma ruptura com a velha ordem, isto é, com o bloco identidade-ser-totalidade e a articulação de um novo ponto de partida: a experiência originária do encontro humano, ou seja, a idéia básica de que o ser humano encontra seu sentido maior em sua relação com outro ser humano, seu próximo, numa relação responsável, de tal modo que 0 outro não seja reduzido no mesmo. 0 núcleo mais profundo do ser humano é este ser para, uma heteronomia que constitui a libertação do ser humano, uma relação face a face, direta, sem mediações, e que pro-

\footnotetext{
${ }^{19}$ Cf. Ibidem, 34.

${ }^{20}$ Cf. Ibidem, 34.

${ }^{21}$ Cf. M. FABRI, op. cit., 19. A preocupação levinasiana é libertar a subjetividade humana de um solipsismo monádico, colocando as raízes da constituição dessa subjetividade humana num nível intersubjetivo, assimétrico, diacrônico que se pretende originário e anterior à ontologia. Ver, a respeito, M. L. CostA, op. cit., 94.

${ }^{22}$ Cf. M. FABRI, op. cit., 182

23 J -F. Rey, Levinas: Le passeur de justice, Paris, Michalon, 1997, 23-43. Nesta perspectiva, diz-nos Costa: "A relação entre os seres humanos não é ontológica (constituição, posse, objetivação, exploração, etc.), mas ética. A ética, mais que relação, é experiência: experimentar na transcendência a vergonha e a culpabilidade de uma ingênua liberdade individual e egoísta que tudo pretende agarrar, objetivar e fazer seu para explorar; experimentar 'em mim a idéia do infinito que é o Outro' como limite do 'eu posso poder' e como primeira aproximação ao Outro; experimentar o desejo metafísico pelo Outro a quem ainda não se acedeu; experimentar o encontro sem mediações com o rosto do Outro estando face-aface com ele; experimentar no 'dito' - falado e ouvido - a inesgotabilidade do 'dizer' que fulgura no rosto do Outro; experimentar a bondade do 'recebimento do Outro em mim', outro que 'vem a $\mathrm{mim}^{\prime}$ assimetricamente pela calçada e de mãos vazias" (M. L. CostA, op. cit., 139).
} 
longa, na área social do cotidiano, a relação com o infinito, que a consciência em relação atesta e que dá à subjetividade humana uma marca de infinitude e de abertura. "Conseqüentemente, é o rosto, no vestígio do infinito, que possibilita ao mesmo descobrir e realizar sua verdadeira e profunda humanidade, para além da velha ordem ontológica" 24 . A ética se instaura, portanto, na relação inter-humana, ela é, então, essencialmente, uma ética da alteridade e constitui o sentido profundo do humano, ${ }^{25}$ precedendo a ontologia e, enquanto tal, é a filosofia primeira. A reviravolta levinasiana consiste, pois, em compreender que o ser é existir. Isto parece indicar uma ruptura com a estrutura teorética do pensamento ocidental ${ }^{26}$.

"Do ponto de vista filosófico, a tarefa de Levinas não foi a de escrever uma nova ética, mas de mostrar que a perspectiva ética deve ser o ponto de partida de toda a filosofia. A descoberta de que eu sou um sujeito infinitamente responsável pela vida do outro é o início de uma meditação em torno da pergunta sobre o ser. A tomada de consciência de minha responsabilidade é o início de cada conhecimento em geral, pois cada conhecimento deve ser purificado de sua tendência natural ao egocentrismo. A base da consciência de si não é a reflexão, mas a relação com o outro. Levinas recusa conceder à dialética hegeliana do senhor e do escravo, à guerra das consciências, o privilégio da origem da consciência de si. Esta é mais o fruto do milagre da saída de si mediante a abertura ao outro, que, antes de ser uma força alienadora que me ameaça, me agride e me esvazia, pode ser uma possibilidade de abertura que rompe as correntes que me prendem a mim mesmo". ${ }^{27}$

\section{A irrupção do outro enquanto outrem infinitamente transcendente}

"'A verdadeira vida está ausente'. Mas nós estamos no mundo"28. Ora, se estamos no mundo e a verdadeira vida está ausente, então, precisamos aspirar, trilhar o caminho à verdadeira vida. A metafísica surge aqui exatamente para o "outro lado", para "doutro modo", para o "outro". Aparece como que um movimento que parte de um mundo que

\footnotetext{
${ }^{24}$ P. S. Pivatto, Ética da alteridade, 91.

25 Para Levinas, o próprio sentido do humano precisa ser revisitado. Levinas anuncia uma vocação à moralidade, à responsabilidade que constitui a característica fundamental de toda pessoa humana. A partir desta concepção levinasiana, pode-se afirmar: ou o ser humano é moral ou não é humano. Ver, a respeito, P. S. Pivatto, Ser moral ou não ser humano, Veritas v. 44, no 2 (1999) 353-367. ${ }^{26}$ Cf. E. Levinas, Entre nós: ensaios sobre a alteridade, Petrópolis, Vozes, 1997, 23.

${ }^{27}$ L. BORDIN, art. cit., 555.

${ }^{28}$ E. Levinas, Totalidade e infinito, 21.
} 
nos é familiar, de uma "nossa casa" que habitamos, para um fora-desi estrangeiro, para um além ${ }^{29}$. 0 termo desse movimento é denominado outro $^{30}$, num sentido eminente. 0 outro metafisicamente desejado não é "outro" como o pão que como, como o país em que habito, como a paisagem que contemplo. "O desejo metafísico tende para uma coisa inteiramente diversa, para o absolutamente outro" ${ }^{31}$. Assim, o desejo não é uma necessidade ${ }^{32}$, pois, se fosse, exigiria uma satisfação e revelar-seia como o "mal do retorno", na ansiedade por complementação, por ampliação ou recuperação de mim, sempre uma nostalgia de mim como terra donde se partiu33. Muito pelo contrário, desejar é sobretudo sair de si para além do horizonte de compreensão do eu. É estabelecer uma relação não "alérgica" com a alteridade. Assim, de acordo com Levinas, o desejo não parte de mim, vem do outro. "O desejo é desejo do absolutamente Outro"34 que me chama à generosidade e à bondade ${ }^{35}$. Diznos Susin:

"Levinas aplica concretamente o surgimento do desejo ao outro, como fez com a idéia do infinito, com o bem além do ser e com o 'Um'. O outro me inquieta, me questiona, me esvazia, me empobrece e me chama secretamente, na sua passagem mesma, na sua visita e na sua partida. M as chama de modo moral à generosidade e à bondade, pois com ele está o bem que gera em mim o desejo de ser bom, de hospedar e de dar dos meus recursos sem dar jamais suficientemente, dar com ardor e imprudência crescente na doação, pois a cada doação ele faz descobrir novos recursos, até então insuspeitados, porque ele

\footnotetext{
${ }^{29}$ Cf. Ibidem.

30 Cf. I bidem.

31 I bidem.

${ }^{32} \mathrm{Cf}$. I bidem, 102. "Se a necessidade é a abertura e a defasagem para a plenificação no gozo e na felicidade, o desejo é abertura pura em direção a uma promessa pura: no desejo, a subjetividade não apenas se sente rompida, como fome incurável mesmo de quem teria suficiente pão da mundaneidade, não só vê reluzir a promessa de uma riqueza diante da qual se sente miserável apesar de toda a riqueza do mundo, mas o desejo mesmo é o surplus e energia sem ardor de necessidade e de eros, surplus puro que provém do infinito e do bem como condição de possibilidade de deportação e de êxodo ao absolutamente além, um movimento que se orienta á altura do Ideal e à humildade de quem é nada neste meu rico mundo" (L. C. Susın, O homem messiânico: uma introdução ao pensamento de Emmanuel Levinas, Petrópolis/Porto Alegre, Vozes/EST, 1984, 266). ${ }_{33}$ Cf. E. Levinas, Totalidade e infinito, 21.

34 I bidem, 22.

35 "O desejo é, assim, o começo da transformação radical do ente em bondade, mas bondade como resposta e responsabilidade a quem está antes e suscita bondade e, portanto, antes de 'saber o que é ser bom', antes de iniciativa como 'decisão de ser bom'. A bondade como 'resposta', por outro lado, não é a criação de uma 'Segunda natureza': como a consciência de si se descobre no seio da consciência moral pela inversão e superação provocadas pelo outro, assim também a necessidade se descobre no seio do desejo - a criatura ex nihilo no seio de uma relação que põe fim à sua orfandade. É uma superação por redução do ser à bondade, do 'natural' ao 'além-do-natural'. Levinas articula esta superação como na idéia do infinito" (L. C. Susın, op. cit., 268).
} 
cava sempre nova fome de generosidade e de doação. Ele é a bondade que, gerando o desejo, não satisfaz a fome de bondade, mas gera mais fome de bondade, sempre insatisfeita e em crescente dívida" ${ }^{36}$.

Como já sabemos, contra a tradição filosófica ocidental, Levinas profere palavras muito duras, pois, segundo ele, esqueceu o outro e procurou assentar o saber teorético tão- somente sobre um eu, reduzindo, na maioria das vezes, o outro ao mesmo ${ }^{37}$. É urgente, por conseguinte, romper com a concepção ocidental hegemônica de que o "saber equivale a ser neutro e a poder dominar 0 outro de tal forma que se torne objeto" ${ }^{38}$. Levinas, no encontro com a fenomenologia, encontrou a possibilidade de uma nova modalidade de desenvolvimento e articulação dos conceitos e da relação entre os seres humanos ${ }^{39}$. Aqui, o outro não nos afeta como aquele que é preciso subjugar, englobar, dominar, mas enquanto outro, independente de nós ${ }^{40}$. Ora, isto, segundo Levinas, significa pôr o saber como próprio existir da criatura, constituindo-se como subida em direção ao outro e, por conseguinte, separando-se de toda uma tradição filosófica que procurava em si o fundamento de si, fora das opiniões heterônomas ${ }^{41}$.

A partir disso, Levinas, pergunta-se: mas como é que o Mesmo, produzindo-se como egoísmo, pode entrar em relação com um Outro sem desde logo o privar da sua alteridade? de que natureza é a relação? Não há dúvidas, diz-nos Levinas, de que a relação metafísica não pode ser uma representação propriamente dita, porque o Outro dissolver-se-ia no $\mathrm{Mesmo}^{42}$. Segundo Levinas, da relação vem a significação de tudo. A presença do outro é o próprio sentido do meu existir ${ }^{43}$. É a relação a uma alteridade irredutível à interioridade da consciência e à mesmidade.

${ }^{36}$ L. C. SUSIN, op. cit., 267.

37 Cf. E. Levinas, Totalidade e infinito, 31.

38 P. S. Pivatto, Ética da alteridade, 83.

39 Cf. Ibidem, 83.

${ }^{40}$ Cf. E. Levinas, Totalidade e infinito, 76.

41 "Pensamos que a existência para si não é o último sentido do saber, mas o pôr em questão de si, em presença de Outrem. A presença de Outrem heteronomia privilegiada - não choca com a liberdade, mas assola-a. A vergonha para si, a presença e o desejo do Outro, não são a negação do saber: o saber é a sua própria articulação. A essência da razão não consiste em assegurar ao homem um fundamento e poderes, mas em pô-lo em questão e em convidá-lo à justiça" (E. Levinas, Totalidade e infinito, 75).

42 Cf. E. Levinas, Totalidade e infinito, 26.

43 "A presença da alteridade provoca uma fissura no eu solipsista, possibilitando uma real transcendência que não significa mais um retorno a si mesmo, mas uma responsabilidade infinita pelo outro" (E. A. KuIAVA, Crítica de Levinas à estrutura da subjetividade kantiana, Veritas v. 44, no 2 (1999) 308). 
"O Outro metafísico é outro de uma alteridade que não é forma, de uma alteridade que não é um simples inverso da identidade, nem de uma alteridade feita de resistência ao Mesmo, mas de uma alteridade anterior a toda a iniciativa, a todo o imperialismo do Mesmo; o outro de uma alteridade que constitui o próprio conteúdo do Outro; o outro de uma alteridade que não limita o M esmo, porque nesse caso o Outro não seria rigorosamente Outro: pela comunidade da fronteira, seria, dentro do sistema, ainda o M esmo" ${ }^{44}$.

De acordo com Levinas, o que vai permitir a saída do egoísmo e do recolhimento do eu em sua casa não é a atitude racional ou a obediência a uma lei moral em sentido kantiano. Somente a contestação da sensibilidade pelo outro é que pode instaurar o reino da razão e da ética. A sensibilidade ${ }^{45}$ é uma forma de resistência a todo sistema ${ }^{46}$. É entendida aqui como exposição ao outro e como vulnerabilidade diante dele. Implica o corpo, o gozo e a matéria como fatores de singularização da subjetividade anterior ao cogito, à consciência e à existência que individualizam ${ }^{47}$. Com outras palavras, para Levinas urge cessar com a descida vertiginosa ao abismo do cogito cartesiano. Neste sentido, 0 outro rompe com a infindável dúvida metódica do eu e está no começo da experiência ${ }^{48}$, visto caracterizar-se sempre como transcendente e jamais suscetível de ser representado pelo mesmo ${ }^{49}$.

0 outro não é o que eu sou. Não é um alter ego, mas um alter do ego. Sua originalidade está exatamente na alteridade que vem de fora, de além do ser, de além do mundo e de outro tempo $0^{50}$. 0 outro não se opõe a mim, apresenta-se como grandeza, como o mestre por excelência. É o absolutamente outrem que não faz número comigo. É o outro desigual, o qual, não sendo o que eu sou em razão de sua alteridade que não é alter ego, está mais abaixo e mais acima de mim, é desigual. Logo, a

\footnotetext{
${ }^{44} \mathrm{E}$. LEVINAS, Totalidade e infinito, p 26. "O respeito da alteridade como alteridade exige que o eu seja como que atraído para fora do seu pólo, que se quebre o esquema do sujeito intencional e se revele um outro núcleo aí presente que, segundo Levinas, é mais profundo, anterior, pré-original e anárquico em relação ao esquema intencional. Ser atraído para fora de si é ser animado pelo desejo, ser inspirado pela idéia do infinito, escutar e obedecer antes de ver" (P. S. PIVATTO, A ética de Levinas e o sentido do humano, 335).

45 A sensibilidade não é intuição ou receptividade, mas contato; é uma nãoiniciativa que não possui começo nem presente. Ver M. FABRI, op. cit., 159.

${ }^{46}$ Cf. Ibidem, 76.

47 Cf. M. L. Costa, op. cit., 166.

48 "O eu na negatividade, que se manifesta pela dúvida, cinde a participação, mas não encontra no cogito sozinho uma paragem. Não sou eu, é o Outro, que pode dizer sim. Dele vem a afirmação. Ele está no começo da experiência. Descartes procura uma certeza e pára na primeira mudança de nível nessa descida vertiginosa. É que, de facto, ele possui a idéia de infinito, pode medir antecipadamente o retorno da afirmação atrás da negação. Mas possuir a idéia do infinito é já ter acolhido Outrem" (E. LevinAs, Totalidade e infinito, 80).

${ }^{49}$ Cf. M. FABRI, op. cit., 99.

${ }^{50}$ Cf. L. C. Susın, op. cit., 199-200.
} 
relação face-a-face será uma relação entre desiguais, uma relação irrecíproca ${ }^{51}$. "O 'outro' que não é 0 'eu' é o 'outro diferente', desconhecido, não-familiar. Não se trata de um outro em posição simétrica ao 'eu', a intersubjetividade a que se refere Levinas é originariamente assimétrica" ${ }^{52}$. Neste sentido, segundo Levinas, a relação face-a-face é uma atitude moral impedida de totalização. Posso sacrificar-me ao outro, mas não posso exigir o sacrifício do outro, não decido por ele. "A responsabilidade para que surja este novo evento e nova história cabe ao eu, a mim; é a mim que cabe ser justo, fazer reinar a ordem da justiça nas relações concretas humanas" ${ }^{53}$. Pois a relação irrecíproca, enquanto o outro é o meu ideal e a relação é sempre uma orientação ao outro, é um risco contínuo, uma incerteza, um despojamento e uma doação contínua, visto não saber nunca previamente 0 outro termo da relação. Não posso ter garantias, não sei 0 que 0 outro vai pedir ou exigir ou revelar, não posso esperar reciprocidade. A alteridade só é possível a partir de mim.

"A transcendência do outro em relação a mim, a sua 'orientação a mim' não tem o mesmo sentido da minha transcendência em relação a ele: 'Jamais minha relação a respeito do próximo é recíproca da relação que vem dele a mim, pois jamais estou quites em relação ao outro. A relação é irreversível'. Assim, não apenas estou impossibilitado de falar 'sobre' o outro a partir de generalizações, mas também não posso sequer falar rigorosamente 'a partir do outro'. Só posso falar a partir de mim e do meu mundo ao outro. Como sou apenas um dos termos da linguagem face-a-face, sou um ponto de vista não abrangente e uma vista que não pode se desfazer do seu ponto de vista. 'A desigualdade está nesta impossibilidade do ponto de vista exterior que a aboliria" ${ }^{54}$.

\subsection{0 rosto como epifania de outrem}

O rosto está presente na sua recusa de ser conteúdo. Não pode ser compreendido nem englobado ${ }^{55}$. 0 rosto do outro ser humano é a sua forma de apresenta-se, não de ser representado, diante do eu que o olha e 0 toca, mas sem objetivá-lo. 0 rosto na relação face-a-face supera a idéia que 0 eu tem do outro. "O face-a-face supera em originalidade e radicalidade as representações inteligidas e a idéia que se pode ter do infinito do 'ser humano' inteligido"56. O rosto é a revelação plena do infinito. "No rosto, no outro brilha de alguma forma a presença enigmática do infinito" ${ }^{57}$. Na presença do rosto abre-se uma dimensão do

${ }^{51}$ Cf. Ibidem, 214.

52 M. L. Costa, op. cit., 92.

3 P. S. Pivatto, A ética de Levinas e o sentido do humano, 344.

54 L. C. Susin, op. cit., 219.

${ }^{55}$ Cf. E. Levinas, Totalidade e infinito, 173.

${ }^{56}$ M. L. Costa, op. cit., 125.

57 P. S. Pivatto, A ética de Levinas e o sentido do humano, 341. 
infinito, despertando um desejo que, para se tornar ético, deve reconhecer o outro como absolutamente outrem. Este, enquanto infinito, é uma alteridade absoluta que se manifesta concretamente na relação ética, que se produz sob a aparência de uma relação com o rosto, o qual permanece sempre absoluto na relação. 0 fundamento, portanto, da relação ética está no encontro com um rosto.

"Outrem permanece infinitamente transcendente, infinitamente estranho, mas o seu rosto, onde se dá a sua epifania e que apela a mim, rompe com o mundo que nos pode ser comum e cujas virtualidades se inscrevem na nossa natureza e que desenvolvemos também na nossa existência" ${ }^{58}$.

0 outro se apresenta "de face", isto é, com seu rosto. 0 rosto é o que eu vejo do outro. É visível. É expressivo. "O rosto não manifesta nem seduz; visita, anuncia e revela" ${ }^{59}$. As expressões do rosto não o deixam aprisionar numa forma plástica. 0 rosto excede todas as suas expressões, sem aprisioná-lo numa somente. "O rosto, na sua essência, é o que resta do outro, uma vez exaurida a ordem de referências à própria existência e ao horizonte do ser e do mundo"60. É, por conseguinte, nudez. É miséria. É exposição. É ideal, altura e mestre. "Provoca desconcerto no eu, como que uma crise no seu poder, ponto crítico da ambigüidade do qual pode resultar tanto 0 assassinato como o transcender do eu, operando a seguir como responsável pelo outro. 0 rosto como mestre ensina 'tu não matarás', sentido que é a própria expressão-rosto" ${ }^{61}$. Segundo Levinas, estar em relação face-a-face é não poder matar. A relação com 0 rosto é relação com o próprio ente, 0 rosto do outro aparece-me numa dimensão de verticalidade e altura ${ }^{62}$ Neste sentido, a miséria do rosto provoca e ensina. Sua nudez expressa 0 encontro com sua vulnerabilidade.

"O rosto recusa-se à posse, aos meus poderes. Na sua epifania, na expressão, o sensível ainda captável transmuda-se em resistência total à apreensão"63. Ter uma idéia do outro é diferente de estar diante do outro, para 0 qual sua idéia é inadequada. A relação ética com 0 outro é linguagem. É rosto. É face-a-face. Não é tematizar o outro no meu mundo, mas compartilhar meu mundo com o outro. A relação com 0

\footnotetext{
58 E. LeVInAS, Totalidade e infinito, 173.

59 P. S. Pivatto, A ética de Levinas e o sentido do humano, 343.

60 Ibidem, 343.

61 Ibidem, 343. "Esse infinito, mais forte do que o assassínio, resistenos já no seu rosto, é o seu rosto, é a expressão original, é a primeira palavra: 'não cometerás assassínio'. O infinito paralisa o poder pela sua infinita resistência ao assassínio que, dura e intransponível, brilha no rosto de outrem, na nudez total dos seus olhos, sem defesa, na nudez da abertura absoluta do Transcendente" (E. LeVInAS, Totalidade e infinito, 178).

${ }^{62}$ Cf. J -F. ReY, op. cit., 27.

63 E. Levinas, Totalidade e infinito, 176.
} 
rosto é linguagem e doação, bondade e justiça, desejo e deixar-ser. 0 face-a-face é a experiência originária por excelência e por isso é ética ${ }^{64}$. 0 núcleo da ética levinasiana é a denúncia do esquecimento do rosto - expressão por excelência - , sentido que escapa a todo contexto e funda a própria ética. A dimensão ética começa a partir da significação do rosto que possui uma estrutura ética. 0 rosto está para além do fenomênico, além do ser. 0 rosto do outro é um mandamento. Resiste ao poder da razão. Irredutível à intencionalidade do ego cogito, chama o eu para fora de si e exige justiça. 0 outro não é objeto intencional, mas movimento novo, integral, que é saída de si mesmo e transcender-se em prol do outro. Neste sentido, a moralidade se funda na possibilidade de acolher outrem, de tal forma que ele tenha primazia sobre o eu. " 0 rosto como vestígio, como enigma, abre no eu o quiasmo do desejo, desarvora a identidade constituída como autonomia e surge como ponto firme de uma relação heterônoma"65. 0 rosto, portanto, comanda e ordena 0 agir moral. A verdade, agora, não é mais adequação do objeto à consciência do eu pensante, mas no acolhimento de outrem. 0 rosto do outro é fundamento da lei moral.

\subsection{0 rosto é apelo à responsabilidade e à justiça}

0 acolhimento de outrem é o começo da consciência moral. Esta surge da idéia do infinito. A consciência primeira da minha imoralidade é a subordinação a outrem, ao infinito. A moral começa, exatamente, quando a liberdade, ao invés de justificar-se por si própria, sente-se arbitrária e violenta. No acolhimento de outrem, o exercício da minha liberdade é posto em questão. Por isso, a consciência moral é posta em questão.

"A consciência primeira da minha imoralidade não éa minha subordinação ao facto, mas a Outrem, ao Infinito. A idéia de totalidade e a idéia do infinito diferem precisamente por isso: a primeira é puramente teorética, a outra é moral. A liberdade, que pode ter vergonha de si própria, fundamenta a verdade (e assim a verdade não se deduz da verdade). Outrem não é inicialmente feito, não é obstáculo, não ameaça de morte. É desejado na minha vergonha. Para descobrir a facticidade injustificada do poder e da liberdade, é preciso não considerar como objecto, nem considerar Outrem como objecto, énecessário medir-se com o infinito e desejá-lo. É preciso ter a idéia do infinito, a idéia do perfeito, como diria Descartes, para conhecer a sua própria imperfeição. A idéia do perfeito não é idéia, mas desejo. É o acolhimento de Outrem, o começo da consciência moral, que põe em questão a minha liberdade" 66 .

${ }^{64}$ Cf. M. L. Costa, op. cit., 141.

65 P. S. Pivatto, A ética de Levinas e o sentido do humano, 343.

${ }^{66}$ E. Levinas, Totalidade e infinito, 71 
Do outro vem o questionamento moral. A entrada do outro desperta para a originalidade da consciência moral e para a sua própria anterioridade, pois a consciência moral é o reconhecimento do privilégio da exterioridade, da anterioridade e da excelência do outro, a partir do qual a justiça, base da consciência moral, é um apelo por justiça jamais suficiente, sempre insatisfeita em direção ao infinito. 0 outro, por conseguinte, provoca em mim a questão moral e porta-me para além da minha vontade e consciência ${ }^{67}$. desperta-me para a responsabilidade, a qual torna-se possível somente a partir da vergonha moral, produzida diante do outro, no contraste entre a minha ingênua soberania, a minha espontaneidade e liberdade arbitrária e potencialmente assassina, por um lado, e a excelência, a humildade e a oferta de paz do outro que me visita $^{68}$. 0 outro, portanto, torna-me vulnerável, confirma minha permanência e não me deixa fugir. Neste sentido, a vergonha, como categoria existencial revolucionária, não é mais um sintoma do mal de ser e necessidade de evasão pura e simples, mas ruptura do círculo da totalidade, onde se fechava a subjetividade solitária., sendo sintoma da presença do infinito e a abertura ao infinito. A vergonha é, pois, a possibilidade de "nascer de novo"69.

É a possibilidade emergente do abandono da egologia e o surgimento da ética como responsabilidade, cuja dedicação ao outro é a própria estrutura, que nos constitui como sujeitos. É o apelo incisivo do outro mais fraco do que nós. Como diz-nos Dostoievski, "Somos todos culpáveis de tudo e todos diante de todos e eu mais do que os outros". Sou sempre responsável pelo outro de modo pleno e inteiro e não restrito a atos ou então à imputação dos atos e suas conseqüências ${ }^{70}$. Não sou livre para decidir onde e quando pode ser suspensa minha responsabilidade. Assim, na perspectiva levinasiana, a ética significa, a partir da minha responsabilidade inalienável pelo outro, responsabilidade que conduz 0 sujeito à substituição $0^{71}$, condição na qual 0 eu toma 0 lugar do outro, respondendo inclusive pelas faltas que ele comete ${ }^{72}$. É a responsabilidade inalienável pelo outro. "A responsabilidade pelo outro chega até a 'substituição' (um em lugar do outro, pela de um sob a pele do outro) que se plasma na figura do 'refém'"'73. É a responsabilidade

\footnotetext{
${ }^{67}$ Cf. L. C. Susin, op. cit., 261.

${ }^{68}$ Cf. I bidem, 262

${ }^{69}$ Cf. I bidem, 264

70 Cf. J -F. ReY, op. cit., 34.

71 “A substituição não é um ato voluntário, altruísta ou desesperado, fundado na liberdade ou na autodeterminação de um sujeito que faz a escolha heróica de dar a vida por alguém. A substituição é pré-originariamente constitutiva da subjetividade, anterior a toda decisão livre de pôr-se em lugar de outro e condição de possibilidade e sentido último de uma tal atitude altruísta. O sentido último do ato está na passividade pré-originária da subjetividade que atua" (M. L. CostA, op. cit., 179).

72 Cf. M. FABRI, op. cit., 146.

73 M. L. Costa, op. cit., 177.
} 
que suporta carregar o outro como a mãe carrega seu filho, quebrando assim a auto-suficiência e 0 individualismo e propondo a construção de uma sociedade a ser humanizada pela fraternidade ${ }^{74}$, a qual supõe relações assimétricas em detrimento das relações de poder, dominação e redução do outro ao mesmo, até então dominantes. A plausibilidade desta proposta submete-se à possibilidade do rompimento com a concepção egoísta da totalidade e à reconstrução da compreensão levinasiana de subjetividade que é afetada pelo infinito ${ }^{75}$ e vem nucleada como responsabilidade ${ }^{76}$. Para melhor compreensão disso que acabamos de afirmar, vejamos como Levinas, sobretudo na obra De otro modo que ser, o más allá de la esencia ${ }^{77}$, constrói sua argumentação acerca da responsabilidade, já que, segundo ele, a tese e o núcleo central da obra é a ênfase da responsabilidade com relação ao outro até chegar à substituição, ou seja, converter-se no para o outro da responsabilidade ${ }^{78}$.

\subsubsection{Responsabilidade e proximidade}

A proximidade é o sentido mais profundo da vida humana. É anterior à consciência como caminho de retorno a si. Não se trata de negar a consciência, mas de recorrer ao nível prévio do saber, a subjetividade singularizada, a qual já significa proximidade, sensibilidade, vulnerabilidade. Levinas, ao distanciar-se da ontologia, recorre à proximidade ${ }^{79}$. Esta eleva-se e vai além do ser. 0 sentido, portanto, não vem mais do ser, assim como não está mais em relação ao ser, mas na relação proximal. Proximidade significa aproximação que, primordialmente, é contato e não equacionamento intelectual do contatado. Não

\footnotetext{
${ }^{74}$ Cf. P. S. Pivatto, Ética da alteridade, 94.

75 Cf. E. Levinas, Totalidade e infinito, 13.

76 “Após a obra Totalidade e infinito, Levinas retoma a questão da subjetividade nucleada como responsabilidade, descreve-a, aprofunda-a sob diversos ângulos a ponto de criar uma nova teoria da subjetividade, surpreendente e provocadora, sob muitos aspectos" (P. S. Pivatto, Responsabilidade e culpa em Emmanuel Levinas, in R. T. DE SouzA, N. F. DE OliveIRA (orgs), Fenomenologia hoje, Porto Alegre, EDIPUCRS, 2001, 312.

77 Far-se-á uso, neste trabalho, da edição espanhola. E. LevinAs, De otro modo que ser, o más allá de la esencia, Salamanca, Sígueme, 1987.

78 "En suma, la tesis de la presente obra es que el énfasis de la abertura sea la responsabilidad respecto al otro hasta llegar a la sustitución, el para el otro del desvelamiento, de la mostración al otro convirtiéndose en para el otro de la responsabilidad" (E. LEVINAS, De otro modo que ser, o más allá de la esencia, 190). 79 "A proximidade não é nem estado de natureza nem estado de consciência, simplesmente não é estado. Não é simbiose aborígene nem consciência que tematiza a vizinhança, o comércio e a política entre um e outro. Relação sem relação, não mediada, imediatez do outro que é subjetividade anárquica (anterior ao arché), implicação, recepção e aceitação do outro que vem a mim significando mais que a origem da 'ab-origem' e mais que a consciência e seu tema" (M. L. Costa, op. cit., 170).
} 
é um saber, mas uma base original possível do saber que, todavia, não se substitui em nenhuma hipótese a esta base original. Trata-se de uma questão de outra ordem. Subjetividade é, portanto, algo irredutível à consciência e à tematização. Anarquicamente, a proximidade é assim uma relação com uma singularidade sem a mediação de nenhum princípio, de nenhuma idealidade ${ }^{80}$.

Ao tratar da proximidade, Levinas inicia perguntando-se: será acaso a proximidade uma certa medida de intervalos traçados entre dois pontos cuja contigüidade e inclusive a coincidência assinalariam o limite? Se assim 0 fosse, o termo proximidade teria um sentido relativo. Mas, pelo contrário, seu sentido absoluto e próprio supõe a humanidade. Neste sentido, pode-se até perguntar se a contigüidade mesma seria compreensível sem a proximidade e se a homogeneidade deste espaço seria pensável sem a significação humana da justiça contra toda diferença e, por conseguinte, sem todas as motivações da proximidade, cujo fim é a justiça ${ }^{81}$. Segundo Levinas, o espaço e a natureza não podem ser colocados em uma impassibilidade geométrica e física iniciais para receber a presença do homem em seus desejos e paixões. Se no começo existissem esta geometria e esta física, os atributos significantes jamais tenderiam a outra coisa senão a uma existência subjetiva na cabeça dos homens e não escaparíamos do narcisismo ${ }^{82}$. Se assim fosse, como entraria, pergunta-se Levinas, a questão da justiça, já que esta derivase de uma significação primeira, ou seja, exatamente de uma significação an-árquica da proximidade ${ }^{83}$.

A proximidade não é um estado, um repouso, senão, precisamente, inquietude, não-lugar, fora do lugar do repouso, que perturba a calma da não-localização do ser que se torna repouso em algum lugar. Logo, a proximidade é sempre insuficiente, jamais demasiado próxima. Não se basta numa estrutura fixa, senão que, quando se representa na exigência da justiça como reversível, recai em relação. A proximidade converte-se em sujeito. Chega ao seu ponto superlativo quando desencadeia a inquietude que não cessa, convertendo-se em única e, desde este momento, esquecendo completamente da reciprocidade. Trata-se de um amor do qual não se espera correspondência. A proximidade é 0

${ }^{80}$ Cf. R. T. DE SouzA, Fenomenologia e metafenomenologia: substituição e sentido - sobre o tema da "substituição" no pensamento ético de Levinas, in R. T. DE Souza, N. F. de Oliveira (orgs), Fenomenologia hoje, 387.

${ }^{81}$ Cf. E. Levinas, De otro modo que ser, o más allá de la esencia, 141. "A J ustiça consiste em reconhecer em outrem o meu mestre. A igualdade entre pessoas nada significa por si mesma" (E. LevinAs, Totalidade e infinito, 59). Para Levinas, somente é possível a existência da justiça se houver privilégio da assimetria sobre a reciprocidade. J ustiça não é comparação, não é proporção, mas contínua correção e superação do mero limite fixado por uma lei objetiva. Ver J-F. REY, op. cit., 56.

82 Cf. E. Levinas, De otro modo que ser, o más allá de la esencia, 141.

${ }^{83} \mathrm{Cf}$. Ibidem, 141. 
sujeito que se aproxima e que, por conseguinte, constitui uma relação na qual eu participo como termo, porém no qual eu sou mais ou menos que um termo. Este excesso ou este defeito me remete para fora da objetividade da relação. Agora, é preciso falar em primeira pessoa. Eu sou um termo irredutível à relação e, sem dúvida, em uma recorrência que me esvazia de toda consistência ${ }^{84}$.

Levinas, na obra De otro modo que ser, o más allá de la esencia, fundamenta a responsabilidade na subjetividade. A subjetividade é rodeada, obsessionada pela alteridade. Existir, então, é suportar, carregar o peso do outro. Responsabilidade, enquanto resposta, é o peso que a subjetividade carrega. Com outras palavras, a responsabilidade qualifica a subjetividade. É o sofrer pelo outro. Significa ser responsável por ele, suportá-lo, estar em seu lugar, consumir-se por el $e^{85}$. Mais. A subjetividade é uma responsabilidade pelos outros, uma vulnerabilidade extrema. 0 retorno a si faz-se desvio interminável. Bem antes da consciência da escolha, o homem aproxima-se do homem. É tecido de responsabilidade ${ }^{86}$.

A proximidade não se resolve na consciência que um ser adquire de outro ser ao qual estimaria próximo enquanto encontrar-se-ia à sua vista ou ao seu alcance e enquanto seria possível captá-lo, tê-lo ou entretê-lo na reciprocidade do aperto de mãos, da carícia, da colaboração, do comércio ou da conservação. Proximidade não está no saber e tampouco na reciprocidade. Proximidade é não-indiferença à presença do outro que me olha. A diferença constitui-se, portanto, como não indiferença e a ruptura com o sistema da reciprocidade como obsessão ${ }^{87}$. A obsessão, enquanto não-reciprocidade e afecção de sentido único irreversível como a

84 "La proximidad no es un estado, un reposo, sino que es precisamente inquietud, no-lugar, fuera del lugar del reposo en un lugar; por tanto, siempre proximidad de un modo insuficiente, como un apretón. 'J amás demasiado cerca', la proximidad no queda fijada en una estructura, sino que, cuando se representa en la exigencia de la justicia como reversible, recae en simple relación. La proximidad, como lo 'cada vez más próximo', se convierte en sujeto. Ella llega a su punto superlativo como mi inquietud que no cesa, se convierte en única y desde ese momento uno olvida la reciprocidad como si se tratase de un amor del que no se espera correspondencia. La proximidad es el sujeto que se acerca y que, por consiguiente, constituye ya relación en la cual yo participo como término, pero en la cual soy más o menos que un término. (...) Desde ahora, es preciso hablar en primera persona. Yo soy un término irreductible a la relación y, sin embargo, en una recurrencia que me vacía de toda consistencia" (Ibidem, 142).

85 Cf. E. Levinas, Humanismo do outro homem, Petrópolis, Vozes, 1993, 119.

${ }^{86}$ Cf. M. FABRI, op. cit., 120. "A subjetividade é um vazio mais vazio que nada, é um órgão em déficit, como pulmão vazio, mas cujo movimento é inspiração: o outro é animação e inspiração, que provoca uma exaltação e uma encarnação. A subjetividade é um vazio como de útero materno, mais vazio do que o vácuo, porque em déficit. É lugar para outro, plataforma, suporte que porta, suporta e já sofre desde o outro e para o outro que só vem ao presente para ser seio do tempo outro" [L. C. Susın, Levinas e a reconstrução da subjetividade, Veritas v. 37, n. 147 (1992) 376].

${ }^{87}$ Cf. E. Levinas, De otro modo que ser, o más allá de la esencia, 143. 
diacronia do tempo que escapa entre os dedos, anula-se em mim nomeando-me em primeira pessoa, isto é, eu sou responsável pelo outro desde sempre. Na perspectiva levinasiana, o humano não nasce nem na decisão nem na obediência. 0 humano é uma possibilidade que nasce do questionamento do ser, da saída da dimensão ontológica. 0 humano introduz um sentido à ontologia. A ética surge, exatamente, quando ninguém pode responder em meu lugar. Para Levinas, ser autêntico significa, então, vencer o medo de superar o esquecimento da responsabilidade ao chamado e de encontrar a dimensão verdadeira do existir e do pensar ${ }^{88}$. É o movimento em direção ao outro em sentido único, sem preocupação do movimento de volta. Mais, exatamente, é 0 aproximar-se de tal maneira que, acima de todas as relações recíprocas que não deixam de se estabelecer entre eu e o próximo, eu sempre tenho dado um passo a mais até ele. Isto somente é possível se este passo é responsabilidade, de tal modo que na responsabilidade existente em mim com relação ao outro eu sempre tenho uma resposta a mais para responder à sua própria responsabilidade. Logo, responsabilidade não é coincidência, e muito menos retorno. É sempre abertura. É o dar-se inexoravelmente ${ }^{89}$.

Todavia, não basta, segundo Levinas, insistir na ruptura da coincidência. Urge romper com a estrutura da sincronia por meio da diferença do Mesmo e do Outro na não-indiferença da obsessão exercida pelo Outro sobre o $M$ esmo $^{90}$. Em Levinas, o privilégio da proximidade com relação à ordem racional, a qual tende, em princípio, a um sistema de puras relações, é a hipóstase ${ }^{91}$ da relação em subjetividade obsessionada por uma obsessão não-recíproca até o próximo. Assim, a subjetividade

${ }^{88}$ Cf. M. FABRI, Levinas e a busca do autêntico, in R. T. DE SouzA, N. F. DE OliveIRA (orgs), Fenomenologia hoje, 77.

89 "Ser eu (Moi) significa, a partir daí, não se poder furtar à responsabilidade, como se todo o edifício da criação repousasse sobre meus ombros. Mas a responsabilidade esvazia o Eu (Moi) de seu imperialismo e de seu egoísmo - seja ele egoísmo da salvação - não o transforma em momento da ordem universal, porém confirma a unicidade do Eu (Moi). A unicidade do Eu (Moi) é o fato de que ninguém pode responder em meu lugar" (E. LevinAs, Humanismo do outro homem, 61). "A responsabilidade é, paradoxalmente, de fora para dentro; ela inverte a tendência de procurar a possibilidade da comunicação em um ir de dentro para fora desde a coincidência da consciência consigo mesma" (R. T. DE SouzA, Fenomenologia e metafenomenologia: substituição e sentido - sobre o tema da "substituição" no pensamento ético de Levinas, 400).

90 "Es preciso insistir en la ruptura de tal sincronía, de tal conjunto, por medio de la diferencia del Mismo y del Otro en la no-indiferencia de la obsesión ejercida por el otro sobre el Mismo" (E. Levinas, De otro modo que ser, o más allá de la esencia, 146).

${ }^{91}$ De Aristóteles aos Padres gregos, a pessoa é a dimensão sustentadora de um ser racional. É dimensão sustentadora porque nada tem de acidental ou de adventício. Não só é substância, como igualmente subsistência. É a hipóstase, ou base, sustentadora do ser intelectual. No ser racional, a substância e a hipóstase pessoal não são somente constituídas pelo elemento anímico, mas também pelo que subsiste: a pessoa é subsistência constituída pela alma como entelequia do corpo. Entendendo por "alma" o princípio que faz de um ser em potencial uma 
não é algo prévio à proximidade na qual se comprometeria ulteriormente. Ao contrário, na proximidade, enquanto relação e termo, é o lugar no qual se tece todo compromisso. É, provavelmente, a partir da proximidade que se deve tratar o problema da subjetividade, visto ser esta uma responsabilidade pelos outros, uma vulnerabilidade extrema ${ }^{92}$. "A subjetividade do sujeito é a vulnerabilidade, a exposição à afecção, sensibilidade, passividade mais passiva que qualquer passividade" ${ }^{93}$. Em Levinas, a subjetividade do sujeito é a sensibilidade como vulnerabilidade. É, enquanto passividade acusativa, resposta a um chamado, a qual, perpassada pelo outro, é marcada pelo infinito. Com outras palavras, 0 outro está imediatamente no cerne da subjetividade precedendo a própria identidade, já que tudo se produz previamente ao despertar da consciência ${ }^{94}$.

A proximidade não é reflexão sobre o estado de alma do eu que se aproxima do próximo. Não é, portanto, uma configuração que se produz na alma. É uma imediatez mais antiga que a abstração da natureza. É tampouco uma fusão. É um contato do outro, e neste estar em contato não se trata nem de investir contra o outro para anular sua alteridade nem tampouco de suprimir o eu no outro, pois o próximo não se deixa preceder por nenhum precursor e apresenta-se dentro de uma contingência que exclui todo a priori ${ }^{95}$. Assim sendo, o próximo me concerne antes de toda assunção, antes de todo compromisso sentido ou rechaçado. É o primeiro a vir sem anúncio de nivelamento, antes de qualquer relação contratada, à margem de qualquer parentesco ou lógica. 0 próximo não me concerne por ser reconhecido como pertencente ao mesmo gênero que eu, mas, antes, pelo contrário, porque é precisamente outro. 0 próximo é irmão. É fraternidade irrecusável. É impossibilidade de recusa96. $\mathrm{M}$ arca-me antes que eu 0 designe. É o gemido do humano totalmente outro.

\footnotetext{
natureza concreta e determinada. A alma é o princípio constitutivo, segundo a qual o homem vive, percebe sensorialmente e pensa. O que para os gregos é a hipóstase, para os latinos é a pessoa, disse Santo Agostinho. Esta decisão de homologar-se com os Padres gregos, levará Agostinho (depois de certas vacilações de linguagem entre "substância", "hipóstase" e "pessoa") a repetir a fórmula trinitária fundamental: "Uma essência e três pessoas". Ver J. M. Rovira Belloso, Pessoas divinas, in X. PIKAZA, N. Silanes, Dicionário Teológico: o Deus cristão, São Paulo, Paulus, 1998, 699-708.

92 Cf. E. LeVInAs, Humanismo do outro homem, 124.

93 "La subjetividad del sujeto es la vulnerabilidad, la exposición a la afección, sensibilidad, pasividad más pasiva que cualquier pasividad" (E. LevinAs, De otro modo que ser, o más allá de la esencia, 103).

${ }^{44}$ Cf. P. S. Pivatto, Responsabilidade e culpa em Emmanuel Levinas, 313.

95 Cf. E. Levinas, De otro modo que ser, o más allá de la esencia, 148.

${ }^{96}$ Cf. Ibidem, 148.
} 
$\mathrm{Na}$ aproximação, eu sou, desde sempre, servidor do próximo, chego sempre já demasiado tarde e culpado deste atraso. Estou como que ordenado desde fora, traumaticamente, por uma autoridade que me dirige. Não é a consciência, nem uma espécie de consciência, que me faz devedor da chegada em atraso ao próximo. Porque a proximidade está à margem da representação, da ontologia, do logos. 0 próximo não se mantém em uma forma. É o totalmente outrem. Nada é mais elevado do que o próximo e, enquanto tal, não pode deixar-me indiferente. "O próximo me golpeia antes mesmo de golpear-me, como se já o tivesse ouvido antes mesmo de falar-me" ${ }^{\prime \prime}$.

De acordo com Levinas, a proximidade mais próxima expressa-se no rosto do outro que me olha. 0 rosto é responsabilidade irrecusável que antecede todo consentimento livre, todo pacto e todo contrato ${ }^{98}$. Escapa a toda representação. 0 descobrimento do rosto é nudez, não-forma, abandono de si, envelhecimento, morrer. 0 rosto é o mais nu que a nudez, pobreza, pele em farrapos (piel a jirones), vestígio de si mesmo. Minha reação frustra uma presença que já é passado de si mesma. É lapso de envelhecimento já perdido, que escapa a toda retenção e altera minha contemporaneidade com o outro. Este outro reclama antes mesmo que eu venha. É atraso sempre irrecuperável. Minha presença não responde à extrema urgência do vencimento. Sou acusado de ter demorado. Mediante esta miséria, o rosto do próximo me obsessiona. "Quanto mais respondo mais responsável sou; quanto mais me aproximo, cuja carga tenho, mais longe estou"99 Nada mais me é indiferente. 0 olhar torna-se imperativo ${ }^{100}$.

"Nesta ordem, o rosto não é mais visto teoricamente, mas acolhido, isto é, o mesmo, abrindo-se na ordem do ser expansivo-identificador, se transcende e responde para além de sua medida e liberdade, isto é, com infinda responsabilidade. Esta nova relação com o rosto em que o mesmo, relativizando a ordem do ser expansivo, se transcende, é a ética da alteridade e inaugura o humanismo do outro homem" ${ }^{101}$.

\subsubsection{Responsabilidade e substituição}

Levinas articula o seu livro, De otro modo que ser, o más allá de la esencia, em torno do quinto capítulo sobre a substituição. Pode-se dizer que é uma das construções mais complexas da última fase do pensamento de

\footnotetext{
97 "El prójimo me golpea antes de golpearme, como si ya lo hubiese oído antes de hablarme" (I bidem, 150).

${ }_{98}$ Cf. Ibidem.

99 "Cuanto más respondo más responsable soy; cuanto más me acerco al prójimo, cuya carga tengo, más alejado estoy" (I bidem, 157)

100 Cf. Ibidem, 156

101 P. S. Pivatto, Ética da alteridade, 90.
} 
Levinas ${ }^{102}$. É a definição de subjetividade como resposta aos seus escritos precedentes, a qual ecoa em seus escritos seguintes ${ }^{103}$. Segundo Pivatto, após a obra Totalidade e infinito, Levinas retoma a questão da subjetividade; descreve-a e aprofunda-a sob diversos ângulos a ponto de criar uma nova teoria da subjetividade, surpreendente e provocado$\mathrm{ra}$, sob muitos aspectos ${ }^{104}$. Trata-se, aqui, por conseguinte, de analisar tão-somente alguns aspectos apontados por Levinas no quinto capítulo da obra, De otro modo que ser, o más allá de la esencia, na tentativa de chegar a compreender a constituição da subjetividade como substituição, visto que a 'substituição' é pré-originária e está na própria constituição da subjetividade" ${ }^{105}$.

Para compreendê-la como tal, é preciso recordar, muito embora de modo breve, o que já foi dito. Na tradição da filosofia ocidental, a subjetividade é "arché" e "princípio" em que a identificação dos seres e de mim mesmo se dá como consciência e consciência de si. Levinas opõe-se a esta tese e articula um outro ponto de partida. Parte da sensibilidade, da singularidade e da proximidade, buscando descrever a subjetividade humana como irredutível à consciência, à representação e à tematização ${ }^{106}$. Para Levinas, "O objetivo é chegar a uma subjetividade constituída para com o outro ser, ser para o outro, um em lugar do outro e um refém do outro, antes de ser ente, sujeito, objeto, imagem, representação, idéia, tema" ${ }^{107}$, exatamente porque a subjetividade é sensibilidade, exposição aos outros, vulnerabilidade, responsabilidade na proximidade dos outros, um-para-o-outro, e porque a matéria é o lugar próprio do para-o-outro, o modo como a significação significa antes de mostrar-se como "Dito" dentro do sistema do sincronismo" ${ }^{108}$.

De acordo com Levinas, o um-para-o-outro não é um defeito de intuição, senão excesso de responsabilidade ${ }^{109}$. Esta, por sua vez, como vimos, não vem de contratos ou convenções. É anterior a qualquer tipo de contrato. Não vem da falta, tampouco da angústia pela própria morte. Sua condição de possibilidade é a alteridade ${ }^{110}$, a qual não é senão

${ }_{102}$ Cf. R. T. DE SouzA, Fenomenologia e metafenomenologia: substituição e sentido - sobre o tema da "substituição" no pensamento ético de Levinas, 379.

103 Cf. L.C. Susın, O homem messiânico, 378.

104 Cf. P. S. Pivatto, Ética da alteridade, 91.

105 M. L. Costa, op. cit., 172.

106 "Partiendo de la sensibilidad, no como saber sino como proximidad, buscando en el lenguaje detrás de la circulación de informaciones el contacto y la sensibilidad, hemos intentado describir la subjetividad como algo irreductible a la consciencia y a la tematización" (E. LevinAs, De otro modo que ser, o más allá de la esencia, 164).

107 M. L. Costa, op. cit., 173.

${ }_{108}$ Cf. E. Levinas, De otro modo que ser, o más allá de la esencia, 136.

${ }^{109}$ Cf. I Ibidem, 164.

110 Cf. P. S. Pivatto, Responsabilidade e culpa em Emmanuel Levinas, 306. 
responsabilidade para-com-o-outro, cuja significação an-árquica e préoriginal não adveio da "consciência de", mas, antes, da proximidade do próximo que, desde sempre, acusa-me de ter chegado atrasado ${ }^{111}$. Portanto, responsabilidade, enquanto princípio de individuação, é a impossibilidade de não-indiferença e de abandono do próximo que se aproxima. "A responsabilidade pelo outro homem, a impossibilidade pelo outro homem, a impossibilidade de abandoná-lo sozinho ao mistério da morte é, concretamente, através de todas as modalidades do dar, a suscepção do Dom último de morrer por outrem"112.

A tese desenvolvida por Levinas dá ênfase à responsabilidade do eu em relação ao outro até chegar à substituição, o para-o-outro do desvelamento, da mostração ao outro convertendo-se em para-o-outro da responsabilidade ${ }^{113}$. Por isso, substituição, para Levinas, não significa tomar o lugar do outro, manter-se dentro do sistema da simetria e troca de papéis, no mundo de inflação do ser, senão uma substituição mais radical, que corresponde ao gesto de pôr-se sob o outro, e que acontece fora de todo sistema antes do mundo, sem lugar, deixando o outro ser, e servindo-0. Concentra-se na fórmula "substituição-do-um-para-o-outro"114. Então:

"No fundo do ser não está o cuidado de si a prevalecer, mas a exposição como significância do um-para-outro. A unicidade não consiste na autonomia, mas em ser para, invertendo, de alguma forma, o movimento centrípeto em centrífugo. A angústia pela morte própria é substituída pela angústia pela morte do outro homem. Assim vislumbra-se abertura para o futuro, para a vida, para a riqueza do pluralismo e da diversidade. Nesta nova visão de subjetividade como responsabilidade resplandece a glória que a bondade esparze. A ética precede a ontologia" ${ }^{115}$.

A substituição do um-para-o-outro não é um ato. É uma passividade inconvertível em ato, aquém da alternativa ato-passividade. Trata-se de outramente que ser. Ser si mesmo é portar a miséria e a falha do outro, inclusive com a responsabilidade que 0 outro possa ter para comigo ${ }^{116}$. É a exposição sem retenção ${ }^{117}$. É passividade ilimitada de um acusativo

${ }^{111}$ Cf. E. Levinas, De otro modo que ser, o más allá de la esencia, 148.

112 E. LeVInAs, Entre nós, 238.

113 "En suma, la tesis de la presente obre es que el énfasis de la abertura sea la responsabilidad respecto al otro hasta llegar a la substitución, el para el otro del desvelamiento, de la mostración al otro convirtiéndose en para el otro de la responsabilidad" (E. Levinas, De otro modo que ser, o más allá de la esencia, 190). 114 L. C. Susın, O homem messiânico, 379.

115 P. S. Pivatto, Responsabilidade e culpa em Emmanuel Levinas, 315.

116 Cf. E. LevinAs, De otro modo que ser, o más allá de la esencia, 180.

117 Cf. Ibidem, 59. Para Levinas, a passividade se torna atividade, heteronomia se inverte em autonomia. O sujeito vulnerável se torna um sujeito forte, capaz de suportar o sofrimento do outro. Ver M. FABRI, Desencantando a ontologia, 161. 
enquanto condição do si mesmo ${ }^{118}$. Ser si mesmo, condição de ser refém, significa ter sempre um grau de responsabilidade superior, a responsabilidade com respeito à responsabilidade do outro119. Diz-nos Susin:

"Na responsabilidade, na sujeição e no serviço, sustentando e suportando, se é culpado por todos. A minha responsabilidade sempre suplementar em relação à responsabilidade que outro pudesse ter por mim, eu o carrego como seu refém: Mesmo inocente e sem ter cometido culpas, sou constituído de tal modo que a culpa do outro é minha por este suplemento de responsabilidade por ele. Ser refém é modo de ser ligado à obsessão, à invasão do próprio sítio que me torna prisioneiro em minha própria casa, inocente porque antes de saber e no entanto obsessionado sem poder me livrar, reduzido a refém: pagar pelo que não fiz, substituindo o pagamento de outro, cuidar de quem não escolhi, responder por uma acusação que não conheço, assumir uma miséria que não é minha" ${ }^{120}$.

A substituição não é um ato voluntário, altruísta ou desesperado, fundado na liberdade ou na autodeterminação de um sujeito que faz a escolha heróica de dar a vida por alguém. A substituição é pré-originariamente constitutiva da subjetividade, anterior a toda decisão livre de pôr-se em lugar de outro e condição de possibilidade e sentido último de uma tal atitude altruísta. 0 sentido último do ato está na passividade pré-originária da subjetividade que atua ${ }^{121}$, pois a subjetividade responsável não se absorve e nem se reduz no ser.

"Porém, o um-para-o-outro, fundamento da teoria enquanto torna possível a relação e o ponto fora do ser, o ponto do desinteresse necessário para uma verdade que não quer ser pura ideologia, não é o que se entende por 'subjetividade comprometida'"' 122.

118 "Cuanto más retorno a Mí, cuanto más me despojo de mi libertad bajo efecto del traumatismo de la persecución, de mi libertad de sujeto constituido, voluntario, imperialista, más me descubro como responsable; cuanto más justo soy, también soy más culpable" (E. LeVINAs, De otro modo que ser, o más allá de la esencia, 180).

119 Cf. Ibidem, 186.

${ }^{120}$ L. C. Susın, O homem messiânico, 382. As palavras "otage" e "hôte" abrem três possibilidades para se compreender o que vem a ser a "substituição" e para se decifrar o enigma do refém. A "substituição" pode ser compreendida como sensibilidade, ou seja, hospitalidade, recebimento. Pode também significar a constituição e singularização da subjetividade como "pele do outro" sob a "minha pele" em que as singularidades não se dissolvem, já que se mantêm as duas peles. Finalmente, a substituição pode ser compreendida como o "ser refém" de um terceiro que substitui o outro que é procurado e perseguido. Ver, a este respeito, M. L. COSTA, op. cit., 171-181.

${ }^{121}$ Cf. Ibidem, 179.

122 "Pero el uno-para-el-outro, fundamento de la teoría en tanto que hace posible la relación y el punto fuera del ser, el punto del desinterés necesario para una verdad que no quiere ser pura ideología, no es lo que se entiende por 'subjetividad comprometida"' (E. LEVINAS, De otro modo que ser, o más allá de la esencia, 210). 
Aqui, o um que está implicado no um-para-o-outro é de um modo totalmente distinto ao compromisso. Não se trata de estar num mundo em que tudo se produz dentro de uma ordem da representação das coisas colocadas em conjunção123. Trata-se, antes, da significação, o um-parao-outro da proximidade, que justifica todo compromisso e torna-me refém do outro, a ponto de conservar toda a paciência de sofrer imposto pelo outro124. "Sofrer pelo outro é ser responsável por ele, suportá-lo, estar em seu lugar, consumir-se por ele $\mathrm{e}^{\prime 125}$.

Por fim, salienta-se ainda que a substituição não é um acontecimento psicológico de compaixão, mas torna possível as paradoxais possibilidades psicológicas do colocar-se no lugar do outro126. Ao contrário, é investidura pelo bem. 0 bem é a responsabilidade indeclinável e jamais assumida em toda liberdade.

"Ser dominado pelo Bem não é escolher o Bem a partir de uma neutralidade, diante da bipolaridade axiológica. 0 conceito de tal bipolaridade já se refere à liberdade, ao absoluto do presente, e equivaleria à impossibilidade de ir aquém do princípio, ao absoluto do saber. Ora, ser dominado pelo Bem é precisamente excluir-se da própria possibilidade da escolha, da coexistência no presente. A impossibilidade da escolha não é aqui o efeito da violência - fatalidade ou determinismo -, mas da eleição irrecusável pelo Bem que é, para o eleito, desde sempre realizada. Eleição pelo Bem que não é precisamente ação, mas a nãoviolência mesma. Eleição, quer dizer, investidura do não intercambiável" ${ }^{127}$.

\subsubsection{Responsabilidade e justiça}

A proximidade convoca à justiça, sendo esta impossível se aquele que a dispensa não se encontra em proximidade ${ }^{128}$. A proximidade não é confusão com o outro. É significação incessante, inquietude para-com-o-outro, impossibilidade de calar-se ${ }^{129}$, "é 0 sentido mais profundo da vida humana e é anterior à consciência como caminho de retorno a si"130. Não se trata de recorrer a um nível prévio ao saber. A subjetividade, antes de significar consciência de si e existência pura, saber e tematização, é subjetividade singularizada que já significa proximidade, sensibilidade, vulnerabilidade. É relação sem relação. É subjetividade an-árquica ${ }^{131}$.

\footnotetext{
123 Cf. I bidem, 221.

${ }^{124}$ Cf.I bidem, 198.

125 E. Levinas, Humanismo do outro homem, 119.

126 Cf. IDEM, De otro modo que ser, o más allá de la esencia, 222.

127 IDEM, Humanismo do outro homem, 96.

128 "La justicia es imposible sin que aquel que la dispensa se encuentre dentro de la proximidad" (E. LevinAs, De otro modo que ser, o más allá de la esencia, 238).

129 Cf. I bidem, 219.

130 M. L. Costa, op. cit., 169.

${ }^{131}$ Cf. Ibidem, 169.
} 
"A proximidade não é uma relação pensada, calculada e medida, tampouco uma reunião preparada com uma agenda temática, prévia e comum. Se o ser humano é capaz de relação e união, é porque originalmente é proximidade, subjetividade sensível e razão 'sentiente'. Proximidade é aproximação numa relação que é não-relação (dito forçado a desdizer-se) pela excedência daquele que se aproxima como sujeito da relação, 'transcendência recortada' a partir dos limites e das impossibilidades frente ao outro" 132.

Contudo, diz-nos, claramente, o próprio Levinas:

"Se a proximidade me ordenasse somente ao outro, não haveria problema em nenhum sentido do termo, nem sequer no mais geral. Não haveria nascido 0 problema, nem a consciência, nem a consciência de si. A responsabilidade para com o outro é uma imediatez anterior ao problema; é precisamente proximidade. É conturbada e se torna problema desde a entrada do terceiro" ${ }^{133}$.

Então, a entrada do terceiro é 0 fato mesmo da consciência ${ }^{134}$, ou seja, a consciência nasce com a presença do terceiro. A relação com o terceiro é a contínua e incessante correção da responsabilidade pela justiça. É o surgimento da consciência, a qual surge prenhe de justiça, sendo esta, portanto, o fundamento daquela. "O fundamento da consciência é a justiça" ${ }^{135}$. Mais. A entrada do terceiro é o próprio fato da consciência que obriga a uma incessante correção da assimetria da proximidade. Introduz a questão da medida da justiça e, com ela, o surgimento da consciência ${ }^{136}$.

Dito isso, cabe apresentar alguns elementos acerca da compreensão levinasiana de justiça e de quem é o terceiro. Para começar, é bom registrar que Levinas não detalhou, pormenorizadamente, com todas as suas implicações e conseqüências, tais questões. Esta opção assumida por Levinas, por um lado, tranqüiliza e acomoda, porque não há muito o que dizer além da relação eu e outro, mas, por outro lado, desafia e inquieta, porque aqui talvez se encontra a tarefa principal dos estudi-

132 Ibidem, 170. “A proximidade não é nem estado de natureza nem estado de consciência, simplesmente não é estado. Não é simbiose aborígene nem consciência que tematiza a vizinhança, o comércio e a política entre um e outro. Relação sem relação, não mediada, imediatez do outro que é subjetividade anárquica (anterior ao arché), implicação, recepção e aceitação do outro que vem a mim significando mais que a origem da 'ab-origem' e mais que a consciência e seu tema" (I bidem, 171).

133 "Si la proximidad me ordenase solamente al otro, 'no habría habido problema' en ningún sentido del término, ni siquiera en el más general. No habría nacido el problema, ni la conconsciencia, ni la consciencia de si. La responsabilidad para con el otro es una imediatez anterior al problema; es precisamente proximidad. Es turbada y se torna problema desde la entrada del tercero" (E. LeVInAS, De otro modo que ser, o más allá de la esencia, 235).

134 Cf. Ibidem, 235.

135 "El fundamento de la conciencia es la justicia" (I bidem, 239).

136 P. S. Pivatto, A ética de Levinas e o sentido do humano, 355. 
osos do pensamento de Levinas, porque convoca a pensar e ver como e se é possível efetivar a passagem da compreensão levinasiana da relação eu-outro-terceiro para os níveis cultural, social, político, econômico e ecológico. Tendo presente este eminente desafio, apresentamos, a seguir, tão-somente alguns elementos expressos pelo próprio Levinas, os quais podem auxiliar na dura jornada na qual os levinasianos poderão, respectivamente, assumir e desenvolver. Eis, brevemente, alguns elementos acerca do que é a justiça e de quem é o terceiro para Levinas.

Justiça é proximidade ${ }^{137}$. É a responsabilidade do um-para-o-outro que chega até a substituição ${ }^{138}$. Agora, já não apenas a condição, outrossim a consciência de ser refém não somente do outro, mas também do terceiro, que se aproximam, cuja originalidade expressa no rosto interpela e convoca a uma resposta de justiça. Por isso, para Levinas, não há justiça sem sofrimento e suplemento de responsabilidade por parte de quem a dispensa. Porque, por um lado, a igualdade sustenta-se na desigualdade de todos, isto é, no excesso dos meus deveres com relação aos meus direitos ${ }^{139}$ e, por outro, porque 0 eu será sempre mais, e jamais suficientemente, responsável pela vida do outro. 0 eu responsável jamais pode omitir-se. É suplemento de responsabilidade. É eleição, a qual, por sua vez, é possibilidade de ir continua e concomitantemente ao encontro do outro e a impossibilidade de saciar a responsabilidade que 0 eu tem para o outro ${ }^{140}$. Aos outros, eu não posso impor nada, mas a mim mesmo, ao contrário, posso impor sempre mais. Isto é justiça, aquilo, injustiça. Logo, a possibilidade da existência do justo só é possível se houver primazia da assimetria em detrimento à reciprocidade e coincidência ${ }^{141}$.

0 terceiro, para Levinas, "é o outro distinto que o próximo, porém é também outro próximo, é também um próximo do Outro e não simplesmente seu semelhante" ${ }^{142}$. Com outras palavras, na proximidade do outro obsessionam-me todos os outros do outro e a obsessão clama justiça. "O outro é de golpe o irmão de todos os outros homens"143. Pois minha relação com o outro, enquanto próximo, confere sentido às mi-

\footnotetext{
137 "La justicia es imposible sin que aquel que la dispensa se encuentre dentro de la proximidad" (E. Levinas, De otro modo que ser, o más allá de la esencia, 238)

138 Cf. Ibidem, 216.

139 “(...) donde la igualdad de todos está sostenida por mi desigualdad, por el exceso de mis deberes sobre mis derechos" (Ibidem, 238).

140 V. TSONGo LuUtu, op. cit., 44.

${ }^{141}$ Cf. J -F. ReY, op. cit., 56.

142 "El tercero es otro distinto que el prójimo, pero es también otro prójimo, es también un prójimo del Otro y no simplemente su semejante" (E. LeVInAS, De otro modo que ser, o más allá de la esencia, 236).

143 "El otro es de golpe el hermano de todos los otros hombres" (Ibidem, 237).
} 
nhas relações com todos os outros. Assim, com a entrada do terceiro a consciência se abre à humanização é à universalidade. Não obstante, urge lembrar que a justiça não é uma legalidade que rege as massas humanas, da qual seriam tiradas as técnicas do equilíbrio social, colocando em harmonia forças antagônicas, o que seria uma justificação do Estado deixado às suas próprias necessidades. "A justiça é impossível sem que aquele que a dispensa se encontre dentro da proximidade"144. Justiça, então, é a contínua correção da assimetria. Estará unida ao facea-face. Não é burocracia, administração, cálculo. Deixar-se-á questionar, interrogar julgar incessantemente pelo rosto do outro ${ }^{145}$.

\section{Conclusão}

0 infinito é alteridade inassimilável, diferença absoluta com relação a tudo 0 que se mostra, se sinaliza, se simboliza, se anuncia e se relembra, se apresenta e se representa e contemporiza com o finito e o mesmo. A relação com o infinito não é conhecimento, mas proximidade, que preserva 0 desmedido do não englobável que aflora ${ }^{146}$. Curiosamente, na medida em que fala do infinito, Levinas não faz senão confirmar 0 finito, valorizá-lo em sua própria condiçãa ${ }^{147}$, que se apresenta de modo excepcional e enigmaticamente na vulnerabilidade do rosto que clama por acolhimento. Para Levinas, a reconstrução da subjetividade pressupõe necessariamente um sujeito que encontrou a liberdade ${ }^{148}$, possibilitada à medida da entrega e resposta responsável ao apelo do outro ${ }^{149}$, pois, pela sujeição ao outro, o eu não se aliena nem se escraviza, mas liberta-se. Neste sentido, a condição da subjetividade é a condição de refém, explicada pela passividade para além da identidade do mesmo.

\footnotetext{
144 "La justicia es imposible sin que aquel que la dispensa se encuentre dentro de la proximidad" (I bidem, 238)

145 Cf. V. Tsongo LuUtu, op. cit., 64.

${ }^{146}$ Cf. E. Levinas, Entre nós: ensaios sobre a alteridade, 89. "O Infinito é o que jamais se deixa abarcar ou integrar numa totalidade. $\mathrm{Na}$ medida em que transborda a idéia adequada, a idéia de infinito é a própria transcendência" (M. FABRI, Desencantando a ontologia, 103).

${ }_{147}$ Cf. I Ibidem, 103.

${ }^{148}$ A responsabilidade não é objeto de escolha pessoal; é investidura anterior à escolha, o outro investe a liberdade, conferindo-lhe sentido. A liberdade tornase moral na relação com a alteridade. Segundo a tese levinasiana, a liberdade só se torna humana se receber uma investidura relacional. Ver, a respeito, $\mathrm{P}$. S. Pivatto, Ser moral ou não ser humano, 361-363.

149 "O Dizer se faz na proximidade. Esta permite descrever a subjetividade como aproximação do outro. Antes mesmo da representação e da consciência, outrem já me concerne, me obsidia e afeta. O ser-afetado é o ser original do sujeito. Em outros termos, o que define a subjetividade em Levinas é a sensibilidade como vulnerabilidade" (M. FABRI, Desencantando a ontologia, 120).
} 
A única maneira, por conseguinte, de confirmar a unicidade e a singularidade da subjetividade é dizer "eis-me aqui", anunciando uma responsabilidade infinita pelo outro150, visto que a subjetividade, enquanto rodeada e obsessionada pela alteridade, carrega o peso da responsabilidade pelo outro ${ }^{151}$.

A presença da alteridade provoca uma fissura no eu solipsista, possibilitando uma real transcendência que significa não mais um retorno a si mesmo, mas uma responsabilidade infinita pelo outro, a qual produz justiça. No acolhimento do rosto do outro instaura-se a justiça. Está no seio da proximidade. A justiça não acontece de modo impessoal. A proximidade convoca à justiça, sendo esta impossível se aquele que a dispensa não se encontra em proximidade ${ }^{152}$. A justiça não é comparação nem proporção. Não é degradação da obsessão nem degeneração do para o outro. Não é diminuição da responsabilidade anárquica, mas, antes, contínua correção na relação assimétrica, já que a entrada do terceiro é o próprio fato da consciência ${ }^{153}$. Então, a consciência surge prenhe de justiça, visto que o fundamento da consciência é a justiça ${ }^{154}$. Sendo assim, não há justiça sem sofrimento, pois a igualdade de todos sustenta-se na minha desigualdade pelo excesso dos meus deveres em relação aos meus direitos ${ }^{155}$. Não há eu sem responsabilidade. Cada um é chamado a responder com responsabilidade: "eis-me aqui para os outros".

\footnotetext{
150 "A passividade do sujeito não o torna apenas uma possibilidade psicológica de se colocar no lugar de alguém; ela explode em Dizer e em sinceridade do testemunho. A ética levinasiana pressupõe um discurso religioso distinto do diálogo e da simples reciprocidade; ela aponta para uma subjetividade que possa dizer 'eis-me aqui', anunciando uma responsabilidade infinita pelo outro. Assim, a relação com outrem implica um sentido que nasce antes da representação" (M. FABRI, Desencantando a ontologia, 166).

151 "A responsabilidade nunca cai sobre o outro. Em Levinas, a responsabilidade é carregada pela subjetividade, pelo eu, pela unicidade do eu. Eu sou responsável e esta responsabilidade emerge na subjetividade do eu. $O$ eu é responsável pelo outro, inclusive por todos os outros, e até pela irresponsabilidade do outro, de todos os crimes que o outro comete. Não poderei, então, acabar assassinado pelo outro? É possível, porque eu acolho o outro como ele é. Não procuro compreender o outro, sou servo do outro, nos diz Levinas. É um risco que se tem a correr. Eu diria, tal risco aponta outra alternativa, diversa e oposta àquela ética que coloca o eu no centro e que subordina o outro e que já acarretou dois mil anos de guerra. Será que uma ética que coloca o eu como responsável pelo outro vai produzir dois mil anos de guerra? É uma aventura que Levinas propõe. É o caminho novo que se pode seguir. Só que agora não é mais o eu que impõe e que determina. É o eu que é responsável pelo outro e por todos os outros" (P. S. Pivatto, A ética de Levinas e o sentido do humano, 360.

152 Cf. E. Levinas, De outro modo que ser, o más allá de la esencia, 238

153 P. S. Pivatto, A ética de Levinas e o sentido do humano, 355.

154 Cf. E. Levinas, De otro modo que ser, o más allá de la esencia, 239.

155 Cf. I bidem, 238.
} 
“Ninguém pode permanecer em si: a humanidade do homem, a subjetividade, é uma responsabilidade pelos outros, uma vulnerabilidade extrema. 0 retorno a si faz-se desvio interminável. Bem antes da consciência e da escolha - antes que a criatura se reúna em presente e representação para se fazer essência - o homem aproxima-se do homem. Ele é tecido de responsabilidades. Por elas, lacera ele a essência. Não se trata de um sujeito que assume responsabilidades ou que se subtrai às mesmas; de um sujeito constituído, posto em si e para si como uma livre identidade. Trata-se da subjetividade do sujeito - de sua não-indiferença a outrem na responsabilidade ilimitada, pois não medida por engajamentos - à qual remetem assunção e recusa de responsabilidades. Trata-se da responsabilidade pelos outros em direção aos quais se encontra desviado, nas 'entranhas enternecidas' da subjetividade que ele rasga, o movimento de recorrência" 156 .

\section{Bibliografia}

BORDIN, L. Judaísmo e Filosofia em Emmanuel Levinas. À escuta de uma perene e antiga sabedoria. Síntese v. 25, no 83 (1998) 559.

COSTA, M. L. Levinas: uma introdução. Petrópolis, Vozes, 2000, 19.

FABRI, M. Desencantando a ontologia: subjetividade e sentido ético em Levinas. Porto Alegre, EDIPUCRS, 1997.

JOÃO PAULO II, Fides et Ratio. São Paulo, Paulus, ${ }^{2} 1998$.

KUIAVA, E. A. Crítica de Levinas à estrutura da subjetividade kantiana. Veritas, v. 44, № 2 (1999).

LEVINAS, E. De otro modo que ser, o más allá de la esencia, Salamanca, Sígueme, 1987.

. Entre nós: ensaios sobre a alteridade. Petrópolis, Vozes, 1997. . Humanismo do outro homem. Petrópolis, Vozes, 1993. . Totalidade e infinito, Lisboa, Edições 70, 1988.

NODARI, P. C. Panorâmica ética da época atual. Teocumunicação v. 30, no 129 (2000).

156 E. LeVInAS, Humanismo do outro homem, 124. 
OLIVEIRA, M. A. de (org.), Correntes fundamentais da Ética contemporânea, Petrópolis, Vozes, 2000.

. Considerações sobre a filosofia na encíclica Fides et Ratio. Revista Razão e Fé 1 (junho de 1999). . Diálogos entre razão e fé. São Paulo, Paulinas, 2000.

PIKAZA, X.; SILANES, N. Dicionário Teológico: o Deus cristão. São Paulo, Paulus, 1998.

PIVATTO, P. S. A Ética de Levinas e o sentido do humano: crítica à Ética Ocidental e seus pressupostos. Veritas v. 37, no 147 (1992).

. Ser moral ou não ser humano. Veritas v. 44, no 2 (1999).

REY, J-F. Levinas: Le passeur de justice. Paris, Michalon, 1997.

SOUZA, R. T de; OLIVEIRA, N. F. de (orgs). Fenomenologia hoje. Porto Alegre, EDIPUCRS, 2001.

SUSIN, L. C. Levinas e a reconstrução da subjetividade. Véritas v. 37, n. 147 (1992).

. O homem messiânico: uma introdução ao pensamento de Emmanuel Levinas. Petrópolis/ Porto Alegre, Vozes/ Est, 1984.

TSONGO LUUTU, V. Penser le socio-politique avec Emmanuel Levinas. Lyon, Profac, 1993.

ULLMANN, R. A. (org.). Consecratio Mundi: Festschrift em homenagem a Urbano Zilles, Porto Alegre: EDIPUCRS, 1998.

Endereço do Autor:

Seminário Maior São Lucas

Rua Leopoldo Miguês, 55

Vila São Lucas - Caixa Postal 61

94400970 - Viamão -RS

E-mail: pcnodari@bol.com.br 